\title{
Ceramic production in the Kur River Basin (Fars, Iran) during the mid-late second millennium BCE. A geochemical and technological characterization
}

BY

Possum Pincé1, Dennis Braekmans2,3, Sylvia Lycke1 and Peter Vandenabeele1

1 Department of Archaeology, Faculty of Arts and Philosophy, Ghent University, Sint-Pietersnieuwstraat 35, 9000 Gent, Belgium

2 Cranfield Forensic Institute, Cranfield Univeristy, Defence Academy of the United Kingdom, SN68LA Shrivenham, United Kingdom

3 Earth and Environmental Sciences, KU Leuven, Celestijnenlaan 200E, 3001 Heverlee, Belgium

\begin{abstract}
:
A total of 119 mid-late second millennium BCE pottery samples from six sites in the Kur River Basin (Fars, Iran) were examined to characterize these ceramics and reconstruct their manufacturing technology and origin of the primary materials. For this, a combined study of handheld XRF and thin section petrography was performed. The geochemical signatures of these ceramics were defined and interpreted in their archaeological and geological framework resulting in the determination of different production processes and clay types used for four ceramic wares (Middle Elamite, Qaleh, Shogha and Taimuran) and the identification of possible outcrops used for Shogha-Taimuran production.
\end{abstract}

Keywords: Non-destructive XRF - Ceramic Petrography - Ceramic production - Mid-late second millennium BCE - Kur River Basin (Iran)

\section{The Kur River Basin during the middle to late $2^{\text {nd }}$ millennium $\mathrm{BCE}$}

The middle to late second millennium BCE occupations in the Kur River Basin of Fars Province, Iran, are identified by the presence of Qaleh, Middle Elamite, Shogha and Taimuran style pottery. These local ceramic phases, which coincide with the Transitional and Middle Elamite phases in Khuzistan (Carter and Stolper, 1984), are dated from 1600-1300 to 900 BCE based on stratigraphic data, stylistic analysis and radiocarbon dates from Tall-i Darwazeh (Sumner, 1994). The beginning of this period is marked by a decrease in the number and size of sites and decline in the cultural unity of the region. This coincided with the appearance of two ceramic traditions in the northwestern part of the basin, namely Middle Elamite and Qaleh. The local Qaleh pottery evolved from and partially overlapped with the earlier Kaftari ware (Sumner, 1972, 1994; Vanden Berghe, 1953-54). The shapes and decoration of Qaleh ware are similar to Kaftari 
ceramics but the painted designs of the Qaleh ware were usually restricted to the vessel shoulders and rims (Carter and Stolper, 1984; Sumner, 1972). They have a buff to red-orange colour and a slip was often applied. The typical vessel forms were cups, bowls, cylindrical vessels, goblets and jars (Carter, 1996). Similar painted buff pottery is found in the Ram Hormuz and Izeh regions of eastern Khuzistan and examples from Haft Tepe are also known (Carter, 1996; Carter and Stolper, 1984). Middle Elamite pottery, on the other hand, shows close parallels in shape and fabric to the lowland Middle Elamite II and III ceramics of the Susiana plain in Khuzistan. In the Kur River Basin, Middle Elamite pottery is found only at the site of Malyan (Carter, 1991, 1996; Jacobs, 1980; Potts et al., 2009). It is a plain ware with a fine to coarse paste and a greenish buff to red-orange or brown colour. A common surface treatment was the use of a slip in a similar or contrasting colour as the underlying paste, and typical shapes include cups/bowls, vats, trays, jars and tall (Elamite) goblets (Carter, 1996). Excavations at Malyan revealed at least four ceramic kilns where Qaleh and Middle Elamite pottery was produced in operation EE39 (level IIIB), and five pottery kilns for Qaleh ware production in BB33. These operations uncovered a large Middle Elamite building, and were part of the EDD excavation area at Malyan that was located on the highest point of the mound, in the western part of the site (Carter, 1996; Potts et al., 2009; Sumner, 1988). The discovery of Middle Elamite pottery, glyptic material and imported goods at the site of Malyan demonstrates a connection of the site with the lowlands in that time (Carter, 1996; Potts et al., 2009).

In the southeastern part of the basin, two new local ceramic traditions appear, Shogha and Taimuran (Sumner, 1994). These wares were typically found together on sites, but generally a higher proportion of Shogha ceramics was present. Shogha ware is often coarse and handmade with a dark orange to orange-buff paste and sometimes a buff or red exterior slip. A quite homogeneous repertoire of dark freehand painted designs of naturalistic figures (such as birds, fishes and mountains) and geometric bands were applied as decoration. There are only a few typical forms consisting of cylindrical beakers, globular jars, bowls and trays (Jacobs, 1980; Vanden Berghe, 1951-52). Taimuran ware is a finer ware, usually a wheel made, with an orangebrown to orange-buff fabric and a thin slip. The painted decoration uses dark geometric designs such as horizontal lines and solid triangles. Shapes are generally limited to different types of jars and bowls and the most distinctive form is the carinated wide-mouth jar with a plain rim (Carter, 1991; Carter and Stolper, 1984; Jacobs, 1980; Potts et al., 2009; Vanden Berghe, 1959). Evidence of Shogha production was found at Tall-i Darwazeh (phase III) and except for one waster at Talli Qaleh, there is no evidence of Taimuran manufacture yet known (Carter and Stolper, 1984; Jacobs, 1980). Sumner stated that, based on stratigraphic data from Tall-i Darwazeh, Taimuran ceramics became more popular towards the end of the Shogha-Taimuran phase. He also proposed that Taimuran ceramics were used by mobile pastoralists and Shogha ware by more sedentary agro-pastoralist groups (Sumner, 1994).

Qaleh, Shogha and Taimuran ceramics were first discovered in soundings made by Vanden Berghe during the 1950s at Tall-i Shogha (also called Tall-i Bozorg), Tall-i Taimuran, Tall-i 
Kamin and Tall-i Qaleh (Haerinck and Overlaet, 2003; Overlaet, 1997, 2007; Overlaet and Pincé, in press; Vanden Berghe, 1951-52, 1953-54). Later excavations at Tall-i Darwazeh by Nicol (1968 and 1970) and at Tall-i Malyan under the direction of Sumner (1971 to 1978) led to the discovery of more stratified Shogha/Taimuran and Qaleh / Middle Elamite occupations. Additional archaeological evidence of mid-late $2^{\text {nd }}$ millennium BCE occupation in the Kur River Basin comes from regional surface surveys combined with some fragmentary historical data from clay tablets and brick inscriptions found at Tall-i Malyan and written sources in the lowlands (Alden et al., 2005; Carter, 1996; Goff et al., 1969; Jacobs, 1980; Nicol, 1971; Sumner, 1972; Sumner, 2003). Besides the small number of excavated pottery kilns, little is known about the production and distribution of these wares. This study aims to improve our understanding of the manufacturing processes and provenance of mid-late $2^{\text {nd }}$ millennium ceramics by examining thin sections and chemical compositions of samples from six sites in the basin and by studying how these chemical compositions are related to ceramic ware, vessel type and decoration, find spot, and subperiod of the vessel (Figure 1).

Figure 1 Map of the Kur River Basin with location of the studied mid-late $2^{\text {nd }}$ mill. BCE sites

\section{Geological framework}

The Kur River Basin is a large endorheic basin in the simple folded belt of the Zagros fold-thrust belt (ZFTB) comprising several northwest-southeast parallel folds that enclose highland valleys (Alavi, 2004; De Schacht et al., 2012; Jacobs, 1980; Moghadam and Stern, 2011; Sepehr and Cosgrove, 2004). These folded, faulted and uplifted bedrock ridges of the Kur River Basin represent Jurassic and Cretaceous formations with differing depositional situations (Alavi, 2004; Minc, 2016; Sepehr and Cosgrove, 2004). The oldest Jurassic-era Surmeh formation consists of massive-to-thick bedded, dolomitic and argillaceous limestones followed by the younger Cretaceous Fahliyan formation, which also contains massive-to-thick bedded limestone combined with argillaceous and some oolitic limestones. The subsequent Gadvan formation is composed of greenish grey to brown marl, shale with marly limestone and (argillaceous) limestone. Grey to brown thick-bedded to massive orbitolina sandy limestone and argillaceous limestone typify the Dariyan Formation and alternating shale, marl, limestone and argillaceous limestone characterize the Kazhdumi Formation. Finally, the youngest Sarvak Formation consists of medium-bedded to massive grey limestone. The most exposed formations in the region are the Cretaceous Sarvak and Dariyan formations (Afghah and Haghighi, 2014; Iran, 1971). Southwest of the basin, younger Tertiary bedrock strata crop out, while to the northeast, in the Zagros Imbricate Zone, Mesozoic ophiolites are exposed (Moghadam and Stern, 2011).

The intermontane plains and foothills are filled with Quaternary silt and clays deposited by fluvial and aeolian activity. The Sivand and Kur rivers flow through these plains, and come together near the archaeological site of Tall-i Sauz (Kehl et al., 2009). 


\section{Materials and methods}

\subsection{Classification of the samples}

A total of 119 ceramics from Tall-i Shogha, Tall-i Taimuran, Tall-i Kamin, Tall-i Darwazeh, Tall-i Qaleh and Tall-i Malyan were examined in this study. These ceramics are part of the Vanden Berghe collection of the Royal Museums of Art and Histroy (RMAH) (Brussels, Belgium) and the Sumner and Alden collections of the Penn Museum (Philadelphia, USA). These ceramics were classified as Middle Elamite, Qaleh, Shogha or Taimuran wares. The last three wares were named after sites in the Kur River Basin where those ceramic styles were first found. A further division into vessel types was made for the Shogha and Taimuran wares, based on their shape and decoration. For this subdivision, we followed the typology devised by Jacobs (1980) from her study of the pottery from Nicol's excavations at Tall-i Darwazeh and ceramics from her own surveys in the basin. In her study, Jacobs tried to relate her types and decorative features with different levels and phases of the Nicol excavation, but no firm chronological correlations could be determined.

Middle Elamite ware, consisting of a range of undecorated buff ceramics with a fine to coarse fabric, can be classified into a few characteristic shapes. This, however, was not possible for the Qaleh ware, except for some goblets and jars, because the vessel forms are more varied and most of our available samples were body sherds. The Qaleh and Middle Elamite ceramics from Tall-i Malyan come from excavated contexts, so these samples can be grouped into the building levels (and thus subperiods) they were found in. In this study, we analyzed sherds from levels IVB, IVA and IIIA in the EDD area of Tall-i Malyan. No sherds from level IIIB of the EDD operation were available for study, as this material remained in Iran after the revolution (Carter 1996). A tabulation of the analyzed sherds with their inventory numbers, ceramic ware, site, type of decoration design, vessel type, petrographic group and hXRF group is found in the Electronic supplementary material.

\subsection{Handheld X-ray fluorescence spectroscopy $(h X R F)$}

To enable an analysis of several large museum objects from the RMAH and compare them to other ceramic fragments, the methodological approach needs to be non-destructive. A choice for handheld X-ray fluorescence analysis (hXRF) provided the required results to build an initial compositional reference that can be integrated with mineralogical research. This non-destructive XRF technique was used to determine the elemental fingerprint of each ceramic sample and vessel. The measurements were performed with the commercial Olympus Innov X Delta Premium instrument. Most samples were positioned in a workstation for measuring but the large, complete vessels from the RMAH were measured in the museum where the instrument was placed on a tripod for controlled positioning. The instrument has a rhodium (Rh) based X-ray 
tube and a polychromatic X-ray beam of $10 \mathrm{~mm}$ diameter (spot size) to excite the targeted sample in front of the probe head. The emerging X-ray fluorescence is detected by a silicon drift detector (SDD). On each targeted location, measurements under two different conditions or modes were performed. The first measurement mode, using an Al Filter, measures the higher Z-elements from $\mathrm{V}$ onwards and was performed in air for $150 \mathrm{~s}$ (live time) with a voltage of $40 \mathrm{kV}$ and a current of $38.7 \mu \mathrm{A}$. The second mode was optimal for measuring the low Z-elements from $\mathrm{Mg}$ to $\mathrm{Mn}$. This was also executed in air for $150 \mathrm{~s}$ (live time) but with a voltage of $10 \mathrm{kV}$ and a current of $50.8 \mu \mathrm{A}$ (no filter). Usually, three different target locations per sample were measured to compensate for heterogeneity within the ceramic. The measurements were taken on a smooth, clean surface and, if possible, on fresh breaks.

The spectral data were processed using the XRF-spectrum evaluation software AXIL (Analysis of X-ray spectra by Iterative Least Squares). This software enables the deconvolution of complex spectra by identifying peaks and net peak areas, while accounting for spectral interferences such as background, peak overlaps, and sum and escape peaks (Van Espen et al. 1986; Vekemans et al. 1995). For further processing of the data, the normalized net peak X-ray intensities are used. No reliable concentrations for individual elements could be calculated due to the lack of dedicated standards for analysis of these types of ceramics. However, the performance, machine drift and quality control of the measurements were documented by analyzing certified reference materials (NIST 98b, NIST 679 and USGS SGR-1b).

\subsection{Thin section petrography}

Thin sections were made of a diverse group of the ceramics $(n=27)$, selected to include a range of wares, sites and, when possible, excavation levels. These thin sections were examined to determine the mineralogical composition of the ceramics, reveal information about the materials and technology used to manufacture these ceramics, and to clarify the chemical variations in the $\mathrm{hXRF}$ analysis. The thin sections were classified into petrographic groups, based on their dominant compositional and technological characteristics. This petrographic grouping was performed independently from other results or characteristics in order to obtain an unbiased classification. The description and identification of all features is based on several reference works regarding ceramic petrography (a.o. Braekmans and Degryse, 2016; Quinn, 2013; Reedy, 2008; Whitbread, 1995). A binocular Olympus BX41 microscope was used for analysis of the thin sections.(Cuomo Di Caprio and Vaughan, 1993; Whitbread, 1986)

The inclusions were mainly argillaceous, they thus have a predominance of clay-sized particles. Different types of argillaceous inclusions can occur, namely clay pellets, clay temper, grog and argillaceous rock fragments (ARF) such as mudstones and siltstones. To differentiate between these types of argillaceous inclusions, the methodology of Whitbread and Cuomo Di Caprio was presently used (Cuomo Di Caprio and Vaughan, 1993; Whitbread, 1986). 


\section{Results}

\section{1 hXRF analysis}

A total of 356 measurements per mode were processed in AXIL after which 17 elements could be detected, namely $\mathrm{Al}, \mathrm{Si}, \mathrm{S}, \mathrm{K}, \mathrm{Ca}, \mathrm{Ti}, \mathrm{Cr}, \mathrm{Mn}, \mathrm{Fe}, \mathrm{Zn}, \mathrm{Ga}, \mathrm{As}, \mathrm{Rb}, \mathrm{Sr}, \mathrm{Y}, \mathrm{Zr}$ and $\mathrm{Nb}$. The intensities of these elements were normalized over the intensity of Si to eliminate instrumental parameters and facilitate the comparison of the measurements. After normalization, $\mathrm{Ca}$ and $\mathrm{Fe}$ appeared to be the most prominent elements, followed by $\mathrm{K}$ and $\mathrm{Ti}$. The high proportion of $\mathrm{Ca}$ is likely related to the abundant calcareous rocks in the mountains surrounding the research area. It is commonly incorporated in the ceramics due to the use of calcareous clay and/or Ca-rich temper (shells, limestone, Ca-rich grog), or it can be additionally deposited within the voids of the ceramics after burial. The latter will be assessed through thin section petrography on a selection of samples. To determine possible compositional groups, bivariate plots were made of the normalized intensities of elements that showed the clearest discriminating ability namely $\mathrm{Fe}$ and Cr. Apart from differing $\mathrm{Fe}$ and $\mathrm{Cr}$ enrichments in the clay matrix, $\mathrm{Zr}$ showed also discriminating capacities and can be used as a proxy for specific sand contribution within the ceramics. All three elements can also be affiliated with the heavy mineral compositions zircon, chromite and assorted Fe-oxides, including ilmenite (Degryse and Braekmans 2013).

The bivariate plot of $\mathrm{Fe} / \mathrm{Si}$ versus $\mathrm{Cr} / \mathrm{Si}$ revealed three compositional groups. The first two groups both show a similar intensity of $\mathrm{Cr}$ but differ in the intensity of Fe (Figure 2). The fine Middle Elamite buff pottery, Qaleh ware from Tall-i Qaleh and part of the Qaleh ceramics from Tall-i Malyan fall into hXRF group 1 with a low intensity of $\mathrm{Fe}$ and $\mathrm{Cr}$, while the Shogha and Taimuran ceramics of Tall-i Shogha, Tall-i Taimuran, Tall-i Kamin and Tall-i Darwazeh are almost all part of group 2, which has a higher intensity of Fe than group 1. The three coarse Middle Elamite buff ceramics from Tall-i Malyan (samples 73-8-344, 73-8-346 and 73-8-325) can also be attributed to the second compositional group, which is more visible on Figure 3 where only the Middle Elamite and Qaleh measurements are plotted. The similarity in composition of the Shogha and Taimuran ceramics suggested in the preliminary study of ceramics from the Kur River Basin presented in Pincé et al. (2016) can be verified with this larger dataset. A third compositional group with a higher intensity of $\mathrm{Cr}$ and low intensity of Fe consisted of several Qaleh ceramics from building level IVB in the EDD excavations at Tall-i Malyan. Additionally, two Taimuran ceramics appeared as outliers with a higher intensity of Cr. The first outlier is sample IR.2510, which is the only measured undecorated cooking pot. It was classified as 'Taimuran' based on the level where it was found at Tall-i Taimuran by Vanden Berghe but differed from the other Taimuran samples in function and lack of decoration. The other outlier is the Taimuran sample 85-55-166 from Tall-i Darwazeh, which is an outlier in the petrographic study as well (Individual $\mathrm{D}$, see infra). Some individual measurements on Shogha and Taimuran ceramics also had higher intensities of $\mathrm{Cr}$, revealing the heterogeneity in the fabric of these wares and the usefulness of taking multiple measurements from each sample. This also shows the utility of plotting three 
separate measurement points for each sample instead of an average of all three measurements. A third outlier (sample IR.0481) was a Shogha sample of Tall-i Taimuran with a higher intensity of Fe.

Figure 2 Bivariate plot of $\mathrm{Fe} / \mathrm{Si}$ vs $\mathrm{Cr} / \mathrm{Si}$ of the analyzed ceramics with a classification into the different ceramic wares and sites

A second bivariate plot (Figure 3) was made of the excavated Middle Elamite and Qaleh ceramics of Tall-i Malyan only to detect possible elemental differences between ceramics of different building levels in Operation EDD, which could not be determined. Figure 3, however, shows a higher Fe intensity of the three coarse Middle Elamite buff ceramics that are part of compositional group 2.

Figure 3 Bivariate plot Fe/Si vs Cr/Si of the Middle Elamite and Qaleh ceramics from the Tall-i Malyan excavations with a classification into the different building levels

Another aspect of the ceramics that might have had an influence on the elemental composition is the vessel type. The Middle Elamite ceramics were classified into cups/bowls, vats, neckless jars, necked jars or goblets, Elamite goblets, spouted jars and open or closed forms with no further determination possible. The Shogha and Taimuran ceramics were divided into vessel types according to Jacobs' typology (Jacobs, 1980). The resulting bivariate plots, however, revealed no difference in composition related to the shapes or vessel types and are thus not presented here. It therefore seems that no differing clay types were used to manufacture different shapes or subtypes of the decorated Shogha-Taimuran ceramics and the Middle Elamite buff ware.

In addition to examining the compositions of ceramics, 33 clay samples from across the Kur River Basin were also studied with hXRF. Before hXRF was performed, the clay samples were fired in an oven at $80^{\circ} \mathrm{C}$ for two days to evaporate the water after which clay pellets were made with a diameter of $2 \mathrm{~cm}$ to obtain a flat surface for measuring. The resulting hXRF data revealed a differentiation in the elemental composition between the clays from the alluvial plain and the clay from the foothills of the Zagros mountains. Clay samples from different spots along the river streams (before and after junction of the Kur and Sivand rivers) also showed a high similarity in elemental composition. More detailed information about these clay samples and the hXRF results have recently been published in Pincé et al. (2018). Here, the compositions of the clay samples are compared with the compositions of the ceramics to detect if similarities in the elemental compositions of the ceramics and clays from different parts of the region are present that might assist in provenance determinations or at least identify generally used clay types. For this, principal component analysis (PCA) on the intensities of elements $\mathrm{Al}, \mathrm{Si}, \mathrm{K}, \mathrm{Ti}, \mathrm{Cr}, \mathrm{Mn}, \mathrm{Fe}, \mathrm{Rb}$, $\mathrm{Sr}$ and $\mathrm{Zr}$ was performed using MICROXRF2 software. Bivariate plots were efficient to detect distinctive elemental groups in this ceramic assemblage but for the comparison with the clay samples, PCA was a more suitable and robust approach, as more elements are taken into account. 
Before the PCA, square roots of the net peak intensities were calculated for the elements used for PCA after which the data were normalized. The intensities of the elements used for this statistical analysis can be found in the Electronic supplementary material. The resulting score and loading plots reveal that the Qaleh and fine Middle Elamite wares have more $\mathrm{Sr}, \mathrm{Cr}$ and $\mathrm{Si}$ than the Shogha-Taimuran and coarse Middle Elamite pottery, which have a higher intensity of $\mathrm{Rb}, \mathrm{Fe}$, $\mathrm{Zr}, \mathrm{Al}$ and Ti. The compositions of the ceramics could not be linked to specific sources in this case, but the results indicate the type of clays used for ceramic production of the Qaleh and fine Middle Elamite ware. The circle on Figure 4 shows the compositional similarity between the Qaleh and fine Middle Elamite wares and the measured alluvial clay sources, suggesting that local, alluvial clays were in general systematically used for the production of these wares. Some Shogha and Taimuran pottery have compositions similar to the colluvial clays, but most ShoghaTaimuran ceramics show no match with the analyzed clay samples opposed to the ceramics from the Neolithic period in this region (Pincé et al. 2018).

Figure 4 Score plot (a) and loading plot (b) of PC 1 and 2 presenting the similarity in composition between the analyzed alluvial clays and the Middle Elamite and Qaleh ceramics

\subsection{Thin section petrography}

The petrographic analysis $(n=27)$ resulted in the determination of four petrographic groups and four individual samples that could not be attributed to one of the distinguished groups. The characteristics of these groups and individual samples can be reviewed in Table 1. Sedimentary rocks, including carbonate-rich deposits, were used as the main geological substrate in these ceramics. The 'Mudstone-limestone' and 'Mudstone - clay pellet' groups as well as the Individual $\mathrm{D}$ sample have significantly more and coarser mineral and rock components (max. $1820 \mu \mathrm{m}$ ) than the 'Fine-grained A' and 'Fine-grained B' groups and individual samples A, B and $\mathrm{C}$ as is visible on Table 1 and Figure 5. The different groups and individuals have various amounts of secondary calcite in the voids. An example of secondary calcite is visible in Figure $5 \mathrm{f}$.

The 'Mudstone-limestone' group $(n=7)$ has unimodal pastes that are remarkable for the abundance of (Fe-rich) mudstones (up to 40\%) and a small number of large angular to subangular limestone fragments $(40-1750 \mu \mathrm{m})$. The mudstones are mostly subrounded and oriented parallel to the vessel walls. The sizes vary between 100 and $2250 \mu \mathrm{m}$. Occasionally, a low number of small quartz, plagioclase and alkali feldspars, biotite and muscovite micas, chert and microfossils (such as echinoids) could be identified. Besides 10 to $20 \%$ spherical vesicles, amorphous vughs and some thin, elongate voids (planar voids and channels) in various sizes are present. Microcracks sometimes appear around the mudstones, and the ceramic matrices are quite well to completely sintered. Shogha and Taimuran ceramics from Tall-i Taimuran, Tall-i Kamin and 
Tall-i Shogha, and two coarse Middle Elamite samples from Tall-i Malyan could be attributed to this group.

The 'Mudstone - clay pellet' group $(n=7)$, on the other hand, is distinguished from the first group by the presence of a large number of (Fe-rich) clay pellets besides mudstones (90-1460 $\mu \mathrm{m})$. These clay pellets are generally equant and rounded, although some subangular pellets also occur. The boundaries are sharp to merging and the colour is usually darker than the clay matrix. Some of these identified clay pellets show well sintered and high fired matrices, which have very similar characteristics as grog. Nevertheless, this type of identified clay pellet occurs systematically at the outer, oxidized margins of the ceramics and decreases towards the core. Therefore, it seems unlikely at this point that this is an intentional presence of grog although temper cannot entirely be ruled out. Additionally, a small amount of microcrystalline calcite and Fe-oxides occur. In some sherds attributed to this group, a few alkali feldspars, quartz, chert, biotite and muscovite micas were identified that all have a fine grain size. This group has a lower percentage of voids (7-15\%) than the first group but more microcracks are present around the clay pellets and mudstone inclusions. The matrices in this group are also quite well to completely sintered. The 'Mudstone - clay pellet' group includes Shogha and Taimuran pottery from Tall-i Darwazeh, Tall-i Taimuran, Tall-i Kamin and Tall-i Shogha. Shogha and Taimuran ceramics from different sites thus appear in both groups, but in the samples from Tall-i Darwazeh only 'Mudstone - clay pellet' pottery was observed.

Groups 'Fine-grained A' $(n=6)$ and 'Fine-grained B' $(n=3)$ have similar microstructural characteristics. Both groups have a fine-grained texture with a few small alkali feldspars, quartz, muscovite and biotite micas, clay pellets and Fe-oxides. The 'Fine-grained A' group, however, also contains limestone fragments, which are only sporadically present in the 'Fine-grained B' group. Moreover, 'Fine-grained B' generally has a lower porosity and a higher sintering. The voids (around $8 \%$ for 'Fine-grained B' and $4-15 \%$ for 'Fine-grained A') include micro- to macrovesicles and vughs and some elongate voids that may partially originate from bioclasts (molluscs). The small, orange spots that were quite predominant in 'Fine-grained B' are most likely iron-rich carbonates coloured by firing. The 'Fine-grained A' group includes Middle Elamite and Qaleh ceramics from Tall-i Malyan, while the 'Fine-grained B' group is only found in Qaleh pottery from Tall-i Malyan and Tall-i Qaleh.

Four samples could not be attributed to any of the above groups. Individual sherds A and B (both Qaleh samples from Tall-i Malyan) have a fine-grained matrix similar to the fine-grained groups. However, the matrix of Individual A is well sintered and contains small carbonate minerals, microfossils, biotite, quartz and plagioclase inclusions. In addition to several small to large mudstones (60-680 $\mu \mathrm{m}$, max. $1430 \mu \mathrm{m})$ and Fe-rich inclusions, which does not appear in either of the two petrographic fine-grained groups. Individual A has a low porosity with only $6 \%$ voids consisting of small to medium vesicles and vughs and some fine elongate voids. Individual sherd $\mathrm{B}$, on the other hand, has no coarse Fe-rich inclusions or bioclast voids like those present in 
Individual A. This sample contains a very small amount of chert, a sedimentary rock (probably mudstone) and some alkali feldspars and small biotite and muscovite micas. Additionally, several small to medium limestone fragments occur. The voids ( $8 \%$ consist of micro to macro elongate voids and some vughs. Individual C (a Middle Elamite sherd from Tall-i Malyan) has an extremely calcareous matrix with limestone fragments in different sizes. Besides these sedimentary rock fragments, a few Fe-oxides, one large clay pellet and a small amount of diopside and muscovite is present. Micro- to macrovughs, vesicles and some elongate voids comprise about 10 to $12 \%$ of the sample. The last sample outlier, Individual D (a Taimuran sherd from Tall-i Darwazeh), has a non-calcareous matrix with many mudstones, some calcite and (large) limestone fragments, Fe-oxides, small biotite and muscovite micas, alkali feldspar and some strongly weathered volcanic fragments. It is a coarse ceramic, similar to the 'Mudstone clay pellet' group but without the presence of clay pellets. Moreover, a few pyroxene grains were identified.

Table 1 Characteristics of the different petrographic groups and individuals

Figure 5 Thin section photomicrographs of selected ceramics from each petrographic group: (a) Mudstone-limestone, (b) Mudstone - clay pellet, (c) Fine-grained A, (d) Fine-grained B, (e) Individual A, (f) Individual B, (g) Individual C, (h) Individual D

\section{Discussion}

\subsection{Ceramic production}

Both thin section petrography and hXRF confirmed the same general groups, namely the fine Middle Elamite / Qaleh and the Shogha/Taimuran groups. Furthermore, Individual D appeared to be an outlier in data acquired through both analytical techniques. There is in this assemblage thus a direct relationship between the groups defined through the compositional and petrographic studies, firmly supporting the archaeological significance of the results obtained from both approaches. However, thin section petrography generated a further subdivision.

The 'Mudstone-limestone' group mainly consists of a large amount of mudstone inclusions. The mostly subrounded shape and variety in sizes of the mudstones indicate a rather natural occurrence of the mudstones. The low percentage of limestone fragments also seem to be part of the used raw materials. The co-occurrence of mudstones and clay pellets in the 'Mudstone - clay pellet' group is unsurprising since both inclusions types have similar physical characteristics and can be closely associated. Petrographic groups 'Mudstone-limestone' and 'Mudstone - clay pellet' could not be differentiated in the hXRF results since the differences between these petrographic groups are mainly related to variation in the type and size of argillaceous inclusions present. The clay pellets in the 'Mudstone - clay pellet' group seem to be an integral part of the same clay deposit. No differentiation in the elemental composition was created by them, which 
seems to exclude an external source. They might have been created, added or increased by the potter during production, but can be naturally present in the clay as a result of sorting and sedimentary processes. Furthermore, the lack of clear elemental differences suggest that the mudstones of both groups come from very similar outcrops, or at least outcrops with a comparable elemental composition. A difference in Ca content might potentially have helped to separate the 'Mudstone-limestone' and 'Mudstone - clay pellet' groups in the hXRF analysis, since limestone fragments only appear in the first group. However, the voids of the ceramics in both groups were partially filled with secondary calcite from post-depositional processes, making $\mathrm{Ca}$ an unreliable element to use for determining compositional groups with either bivariate plots or PCA.

The well-to-completely sintered matrices observed in the thin sections indicate a high firing temperature for the ceramics of both petrographic mudstone groups. This firing process seems to have been quite well-controlled since the number of voids or cracks are low compared to the abundance of inclusions in both groups. The differences in sintering observed between the samples might be related to the addition of clay that contained variable amounts of salt. Salt can lower the melting temperature and thus the sintering process, and salty clay deposits are a common feature in the plain around Tall-i Darwazeh (Peacock et al., 1986; Von der Crone, 1994). Although one of the classical criteria differentiating Shogha from Taimuran wares is firing temperature, there is no clear difference in the intensity of firing visible between these wares in the dataset examined here. Depending on the addition or natural presence of the clay pellets in the 'Mudstone - clay pellet' group, the presence of these clay pellets in the 'Mudstone - clay pellet' group and the lack of this type of inclusions in the 'Mudstone-limestone' group may indicate the use of two different selection and manufacturing processes in making both Shogha and Taimuran wares. The lack of compositional differentiation in the vessel types of painted Shogha and Taimuran pottery from different sites suggests that these differing production practices or raw materials were not related to the vessels' functional shape. The difference between the 'Mudstone-limestone' and 'Mudstone - clay pellet' groups, however, might have been influenced by other socio-cultural processes, and be related to chronological variation, or could distinguish the products of different production sites. The latter possibility may be supported by the attribution of all thin sectioned ceramics from Tall-i Darwazeh to the 'Mudstone - clay pellet' group while Shogha and Taimuran ceramics of both 'Mudstone - clay pellet' and 'Mudstonelimestone' types appeared at other sites. Ultimately, because the temper and firing of Shogha and Taimuran ceramics are so similar, the main feature differentiating these two types of ceramics are the painted designs used to decorate them. The thin sections of two (73-8-344 and 73-8-346) coarse Middle Elamite ceramics that were part of the Shogha-Taimuran compositional group defined through XRF were also petrographically similar to Shogha-Taimuran ceramic pastes in that they were both part of the 'Mudstone-limestone' group.

The Middle Elamite and Qaleh ceramics of the 'Fine-grained A' and 'Fine-grained B' petrographic groups were made of fine-grained marly clays. In some samples of 'Fine-grained A' 
there is a colour and compositional variation indicating the use of two marl types that had not been entirely homogenized by working. The clay types differed in the ratios of clay to carbonate minerals but generally had a similar mineralogical composition. The mixture with marls lower in carbonate minerals may have been deliberate, perhaps to alter the character of the ceramic fabric or to minimize breakage during the manufacturing process. Alternatively, it might represent heterogeneity in a single clay source or the exploitation of two different sources. The number of limestone fragments in the 'Fine-grained A' group was limited, suggesting a natural presence in the clay. This also seems to be the case for the very low quantities ( 0 to $5 \%$ ) of small subangular quartz (15-55 micron) in both these fine-grained groups. Although both fine chaff and grit temper often seemed to be present macroscopically, the petrographic analysis indicated that the only clearly added temper was chaff. Comparison of the voids from burned out chaff temper between the ceramics of both groups shows that systematically a lower amount of chaff temper was used in the Qaleh pottery.

\subsection{Provenance of the raw materials}

Although kilns for producing Middle Elamite and Qaleh wares were found at Malyan, it was until now not possible to identify the sources of the clays that the Malyan potters used. The PCA analysis of the ceramics and clay samples, combined with the petrographic results, now indicate that fine-grained secondary clays of a probable local alluvial origin were used for the production of these ceramics.

The presence of two fine-grained petrographic groups and two fine-grained individuals shows some variability in the mineral composition of these wares. Unfortunately, any compositional difference between the two petrographic groups was too small to be reflected in the hXRF results. The petrographic variability could indicate the use of different but similar clay outcrops containing differing proportions of carbonate minerals or alternatively reflect variability within a single clay source exploited for the production of these ceramics. For the Qaleh and fine Middle Elamite ceramics, the only sample that was clearly made from a different clay source is Individual sample C. Compositional group 3 (Qaleh ceramics from Area EDD level IVB at Malyan), which shows a higher intensity of $\mathrm{Cr}$, could not be distinguished as a separate petrographic group. Instead, this hXRF group appeared in both 'Fine-grained A' and 'Finegrained B' petrographic groups as well as Individual B. The lack of distinguishable inclusions in the samples of compositional group 3 suggests the use of a separate source of fine-grained clay, enriched in $\mathrm{Cr}$, and thus a source that may have been exploited only during level IVB times of the EDD excavations. $\mathrm{Cr}$ is often accumulated with the clay itself and might be considered a marker here for a different clay source (Degryse and Braekmans, 2013). If this were the case, the lack of Qaleh ceramics in the higher Cr group at Tall-i Qaleh might indicate that the analyzed ceramics from that site were contemporary with levels IVA and IIIA of Operation EDD at Tall-i Malyan. 
Generally, no match occurred between the Shogha/Taimuran ceramics and the analyzed clays of the region, which might be due to the lack of a clay sample that matches the clay type of the used mudstone-rich clay outcrops. The likely natural presence of the mudstones, however, suggests a procurement of colluvial clays that were eroded and extracted not far from the original mudstone outcrop or residual clays that were weathered in situ. Based on the available geological data, the closest possible outcrop of these mudstones to Tall-i Darwazeh, a known production site of Shogha ware, is $7 \mathrm{~km}$ north of the site (Figure 6). The substrates of this outcrop consist of (argillaceous) limestones, marls and shales from the Kazhdumi and Dariyan Formation, labeled ' $\mathrm{K}_{\mathrm{kz}}$ ' and ' $\mathrm{K}_{\mathrm{dr}}$ ' on the 1:100 000 geological map. Since ethnographic studies indicate that the upper limit of clay exploitation lies at an approximate distance of about $7 \mathrm{~km}$ from a ceramic production site (marked as a circle around known Shogha/Taimuran production sites on Figure 6), this outcrop is a plausible source of the mudstones and clays used in the Shogha and Taimuran ceramics (Arnold, 1985). It must be kept in mind, however, that small pocket deposits with mudstones might be present that are not shown on the geological map. Moreover, at Tall-i Darwazeh the inclusions comprise of both mudstone and clay pellets, while ceramics with a solely dominant presence of mudstone appear at other Shogha-Taimuran sites. Furthermore, the mudstone-bearing Kazhdumi and Dariyan Formations are quite close to Tall-i Shogha and Tall-i Kamin, as is visible on Figure 6. Based on these observations, it is possible that the Shogha-Taimuran ceramics with typical clay pellets (or perhaps even grog temper in some cases) were produced at Tall-i Darwazeh, while the ceramics with mudstones as the primary inclusions were solely produced at other sites. However, more thin sections and clay samples need to be studied to test this hypothesis.

Figure 6 Location of the analyzed clays and the two known production centers with a radius of 7 $\mathrm{km}$ around the sites. For the production of the Shogha and Taimuran ceramics a possible source could be determined at the northern border of the circle around Darwazeh

Individual sample $\mathrm{D}$ is an outlier in both compositional and petrographic analysis. The higher presence of $\mathrm{Cr}$ compared to the other Shogha-Taimuran ceramics is most likely related to the presence of mafic minerals (pyroxene) and rock fragments visible in the thin sections. Analysis of the geology in the broader region shows ophiolitic outcrops about $120 \mathrm{~km}$ north of the study area that might have comprised suitable clay sources used for the production of Individual D. A possible non-local origin of the clay used to manufacture sample D can thus not be excluded.

\section{Conclusions}

To conclude, handheld XRF analysis was able to determine elemental compositions of the ceramics and clays, and identify compositional fingerprints for different groups of ceramics. Thin section petrography facilitated to elucidate the underlying features distinguishing these compositional groups. Additionally, the petrographic results revealed information about ceramic production processes and the type of primary materials used in making these ceramics. 
For the production of Shogha and Taimuran pottery similar types of clay outcrops seem to have been used, which were probably of a colluvial or residual origin. The mudstone inclusions most likely occur naturally in the raw material and the only selection or addition of material that might have been used in some of the Shogha and Taimuran vessels are clay pellets. These can be associated with a production at Tall-i Darwazeh, although additional samples should more firmly verify this hypothesis. The inclusion and firing characteristics of both wares in this dataset are very similar so the main distinctive feature between the Shogha and Taimuran wares are the designs of the painted decoration on the vessels. Thin section petrography further revealed a controlled firing process and high firing temperature for both wares. This studied assemblage provides evidence for a similar selection of raw materials and manufacturing processes for the production of the studied coarse buff Middle Elamite ceramics. The fine buff Middle Elamite and Qaleh ceramics, on the other hand, were made of different, fine-grained marly clays of a probable alluvial origin. This difference is further supported through the identification of chaff as the only added temper in these ceramic styles. The amount used for the Qaleh ware is lower than for the Middle Elamite samples. The combination of hXRF analysis and thin section petrography confirmed a local production of both the fine and coarse buff Middle Elamite ceramics in this assemblage.

The identification of discrete production groups and selection practices improve our understanding of the ceramic production in the Kur River Basin during the middle to late $2^{\text {nd }}$ millennium BCE. When more production-related artefacts are found, in correlation with both ceramics and systematically surveyed clay sources, it should be possible to address these remaining issues to complete the past socio-economic and cultural context.

\section{Acknowledgements}

We would like to express our gratitude to Prof. Dr. Holly Pittman and Katherine Blanchard of the Penn Museum (Philadelphia, USA) and Dr. Bruno Overlaet of the Royal Museums of Arts and History (Brussels, Belgium) for permitting us to study and analyze the museum collections. Furthermore, we would like to thank Negar Abdali, Sheler Amelirad and Prof. Dr. Morgan De Dapper for their valuable help with the samples and Eric Goemaere for his useful comments on the thin sections. Finally, we are very grateful to Dr. John Alden for his detailed proofreading of the paper. His comments led to a substantial improvement of many aspects of this paper.

We are also grateful to the Belgian Science Policy Office (BELSPO), who funds this research project that is part of the BRAIN-project BArEO (Belgian Archaeological Expeditions to the Orient. Heritage in Federal Collections), BELSPO project no. BR/121/A3/BAREO.

\section{References}


Afghah, M., and A. S. Haghighi, 2014, Aptian biostratigraphy in South Zagros Basin, Southwest Iran, Geoscience Frontiers, 5, 277-288.

Alavi, M., 2004, Regional stratigraphy of the Zagros Fold-Thrust Belt of Iran and its proforeland evolution, American Journal of Science, 304, 1-20.

Alden, J. R., K. Abdi, A. Azadi, G. Beckman, and H. Pittman, 2005, Fars Archaeology Project 2004: Excavations at Tal-e Malyan, Iran, 43, 39-47.

Arnold, D. E., 1985, Ceramic Theory and Cultural Process: Cambridge, Cambridge University Press.

Carter, E., 1991, Ceramics viii. The Early Bronze Age in Southwestern and Southern Persia, Encyclopaedia Iranica, 5, 294-297.

Carter, E., 1996, Excavations at Anshan (Tal-e Malyan) - The Middle Elamite Period, in University Museum Monograph 75, 137, University of Pennsylvania, Philadelphia.

Carter, E., and M. W. Stolper, 1984, Elam : surveys of political history and archaeology, v. 25: Berkeley and Los Angeles, Berkeley University of California press.

De Schacht, T., M. De Dapper, A. Asadi, Y. Ubelmann, and R. Boucharlat, 2012, Geoarchaeological study of the Achaemenid dam of Sad-i Didegan (Fars, Iran), Géomorphologie: relief, processus, environnement, 1, 91-108.

Degryse, P., and D. Braekmans, 2013, Elemental and isotopic analysis of ancient ceramics and glass, in Treatise on geochemistry, 191-207, H. D. Holland, and K. K. Turekian, eds., Elsevier, Oxford.

Goff, C., L. Vanden Berghe, F. Hole, M. B. Nicol, H. T. Wright, E. O. Neghban, C. A. Burney, R. H. Dyson, O. W. Muscarella, M. M. Voigt, M. Tosi, D. Whitehouse, M. -J. Steve, C. C. Lamberg-Karlovsky, R. R. B. Kearton, W. Kleiss, R. S. Solecki, T. A. Wertime, P. Gotch, and D. Huff, 1969, Survey of Excavations in Iran, 1967-8, Iran: Journal of the British Institute of Persian Studies, 7, 169-193.

Haerinck, E., and B. Overlaet, 2003, Soundings at Tall-i Qaleh (Hasanabad), Fars Province, Iran, in Yeki bud, yeki nabud. Essays on the Archaeology of Iran in honor of William M. Sumner, N. F. Miller, and K. Abdi, eds., Los Angeles.

Iran, G. S. o., 1971, Geological Map of Iran, 1:100 000, Sheets: Sivand, Saadatshahr, Shiraz, Arsenjan, Geological Survey of Iran, Tehran.

Jacobs, L. K., 1980, Darvazeh Tepe and the Iranian highlands in the second millennium B.C., University of Oregon, London, 355 p.

Kehl, M., M. Frechen, and A. Skowronek, 2009, Nature and age of Late Quaternary basin fill deposits in the Basin of Persepolis/Southern Iran, Quaternary International, 196, 57-70.

Minc, L. D., 2016, Trace-element analyses of Uruk ceramics: Establishing a database to track interregional exchange, Journal of Archaeological Science: Reports, 7, 798-807.

Moghadam, H. S., and R. J. Stern, 2011, Geodynamic evolution of Upper Cretaceous Zagros ophiolites: formation of oceanic lithosphere above a nascent subduction zone, Geological Magazine, 148(5-6), 762-801.

Nicol, M. B., 1971, Darvazeh Tepe, Iran, IX, 168-169.

Overlaet, B., 1997, A report on the 1952 and 1954/55 soundings at Tall-i Taimuran (Fars), Iran A file-excavation at the Royal Museums of Art and History, Brussels, Iranica Antiqua, 32, $1-51$.

Overlaet, B., 2007, Soundings at Tall-i Kamin (Kur River Basin), Fars, Iran, Iranica Antiqua, XLII, 61-103.

Overlaet, B., and P. Pincé, in press, The "hill of the jackal" - The 1951 excavations at Tall-i Shogha, Iran., Iranica Antiqua, 52. 
Peacock, D. P. S., F. Bejaoui, and N. Belazreg, 1986: Amphores romaines et histoire économique. Dix ans de recherches. Actes du colloque de Sienne (22-24 mai 1986), p. 179-222.

Potts, D. T., K. Roustaei, L. R. Weeks, and C. A. Petrie, 2009, The Mamasani District and the Archaeology of Southwestern Iran, in The Mamasani Archaeological Project Stage One: A report on the first two seasons of the ICAR - University of Sydney expedition to the Mamasani District, Fars Province, Iran, 1-16, D. T. Potts, K. Roustaei, C. A. Petrie, and L. R. Weeks, eds., BAR International Series, S2044, Archaeopress, Oxford.

Sepehr, M., and J. W. Cosgrove, 2004, Structural framework of the Zagros Fold-Thrust Belt, Iran, Marine and Petroleum Geology, 21, 829-843.

Sumner, W. M., 1972, Cultural development in the Kur River Basin, Iran - An archaeological analysis of settlement patterns, University of Pennsylvania, Michigan, $296 \mathrm{p}$.

Sumner, W. M., 1988, Maljan, Tall-e (Ansan), 306-320, E. Ebeling, and B. Meissner, eds., Reallexikon der Assyriologie und Vorderasiatischen Archäologie, de Gruyter, New York.

Sumner, W. M., 1994, The evolution of tribal society in the southern Zagros mountains, Iran, in Chiefdoms and early states in the Near East - The organizational dynamics of complexity, 47-66, G. Stein, and M. S. Rothman, eds., Monographs in World Archaeology, Prehistory Press, Madison.

Sumner, W. M., 2003, Early urban life in the land of Anshan: Excavations at Tal-e Malyan in the highlands of Iran, 219, Malyan Excavation Reports, University of Pennsylvania, Philadelphia.

Vanden Berghe, L., 1951-52, Archeologische opzoekingen in de Marv Dasht vlakte (Iran), Jaarbericht Ex Oriente Lux, 12, 211-220.

Vanden Berghe, L., 1953-54, Archeologische navorsingen in de omstreken van Persepolis, Jaarbericht Ex Oriente Lux, 13, 394-408.

Vanden Berghe, L., 1959, Archeologie de l'Iran ancien, Documenta et Monumenta Orientis Antiqui, Leiden.

Von der Crone, M. J., 1994, Der Einflus des Meerwassers auf die Weissfärbung beim Brennen keramischer Massen, Universität Frieiburg, Switzerland.

\section{Electronic supplementary material}

Table.2 Overview of the analyzed sherds with additional information

Table.3 The intensities of the elements used for statistical analysis 
Figures and Tables

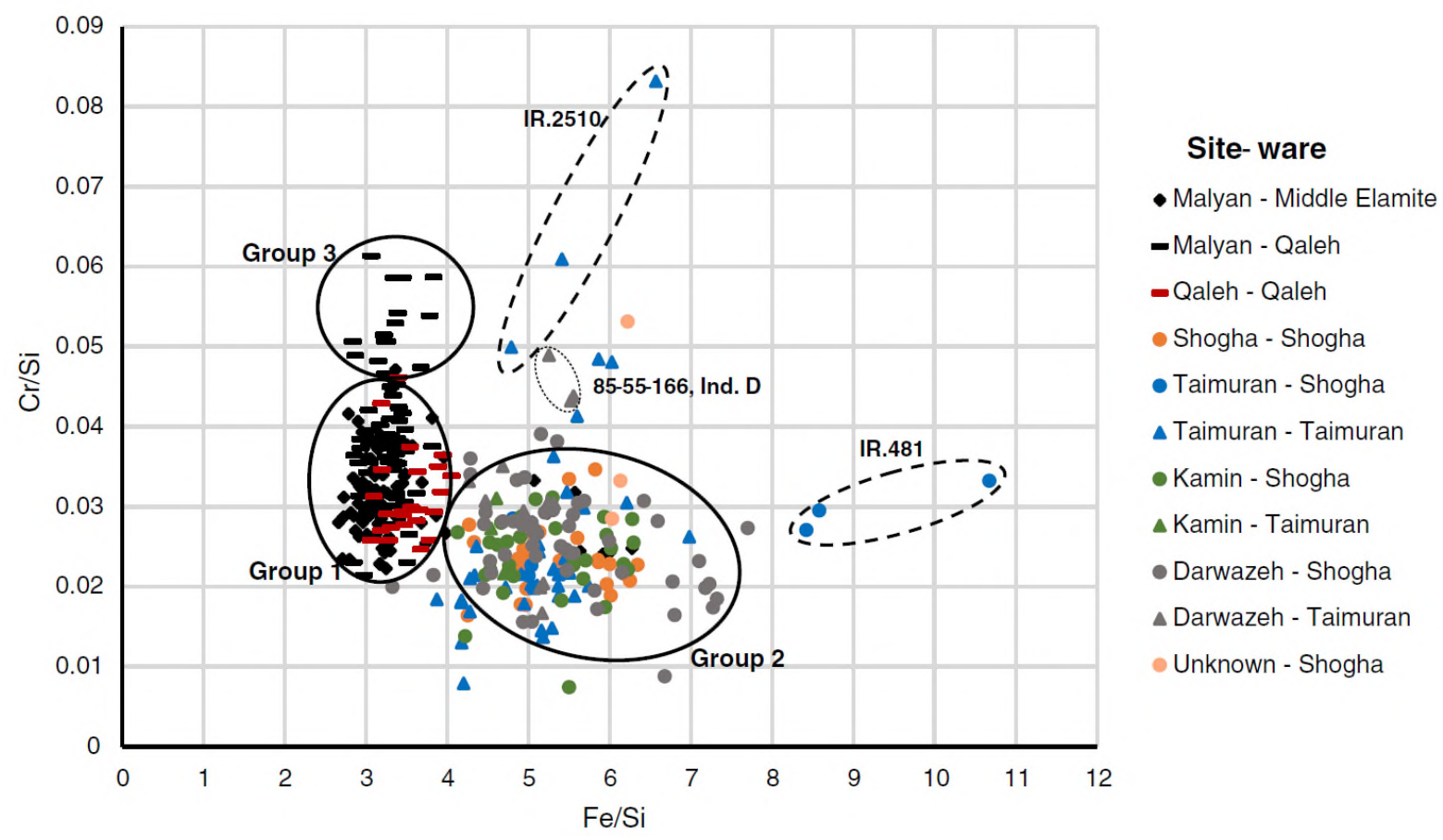

Figure 1 The bivariate plot of Fe/Si versus $\mathrm{Cr} / \mathrm{Si}$ of the analysed ceramics, with a classiï $\neg$ cation into the different ce-ramic wares and sites.

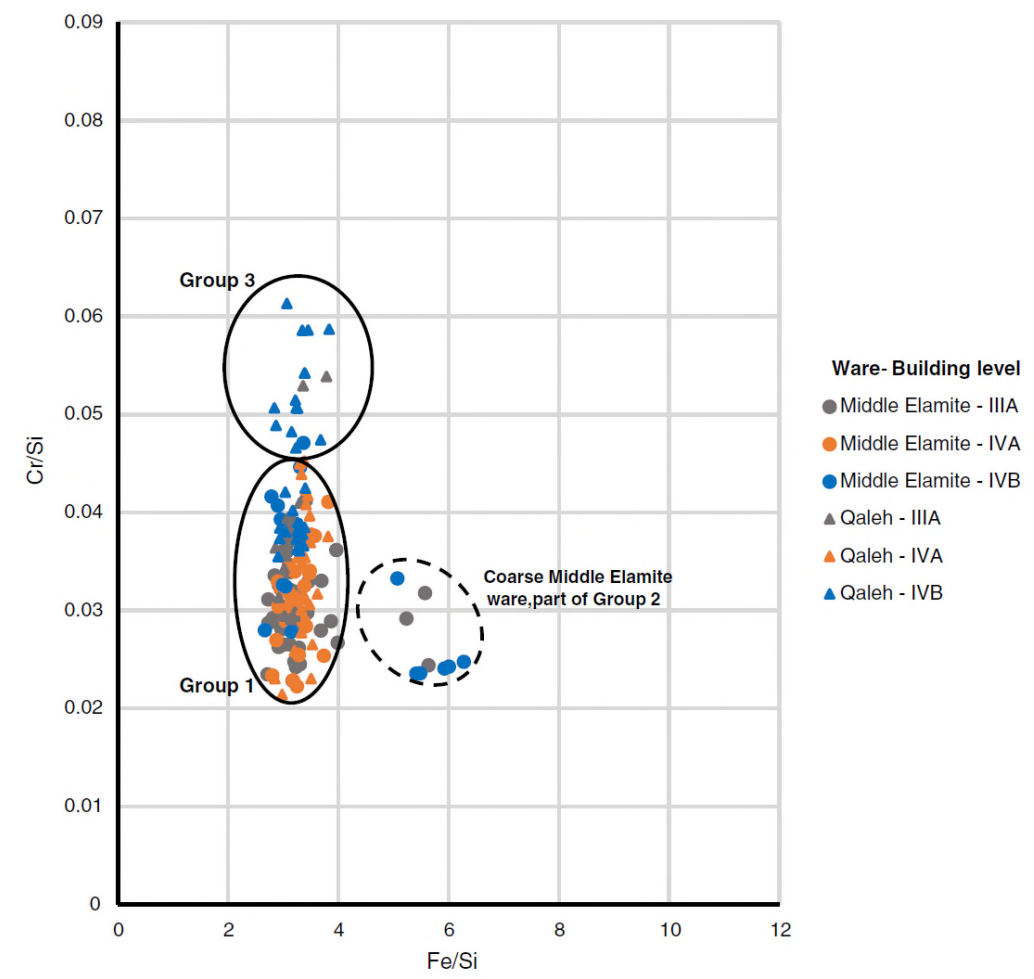

Figure 2 The bivariate plot Fe/Si versus Cr/Si of the Middle Elamite and Qaleh ceramics from the Tall-i Malyan exca-vations, with a classification into the different building levels. 


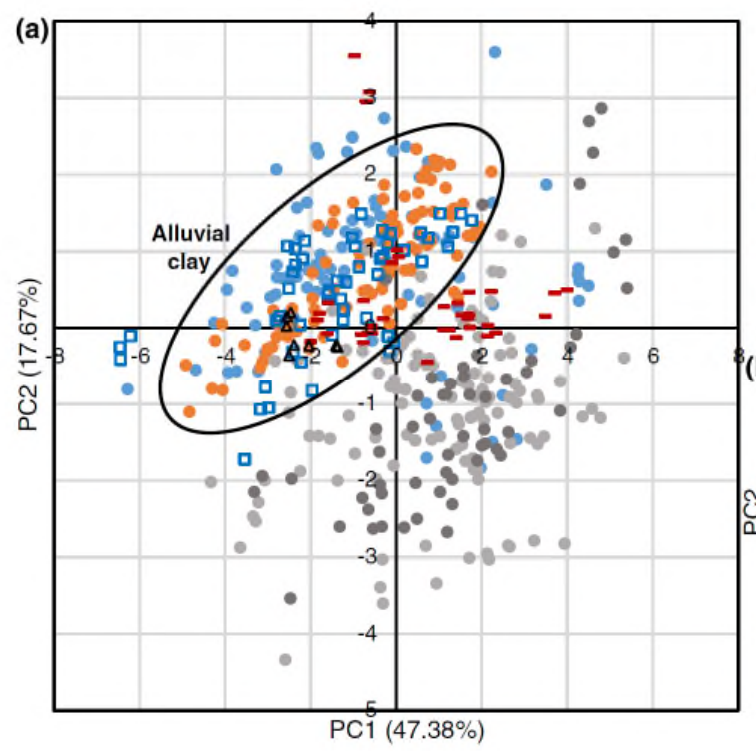

- Middle Elamite ware

- Qaleh ware

- Shogha ware

- Taimuran ware

口Alluvial clay

- Colluvial clay

$\Delta$ Riverbank clay

Figure 3 The score plot (a) and loading plot (b) of PC 1 and 2, presenting the similarity in composition between the analysed alluvial clays and the Middle Elamite and Qaleh ceramics.
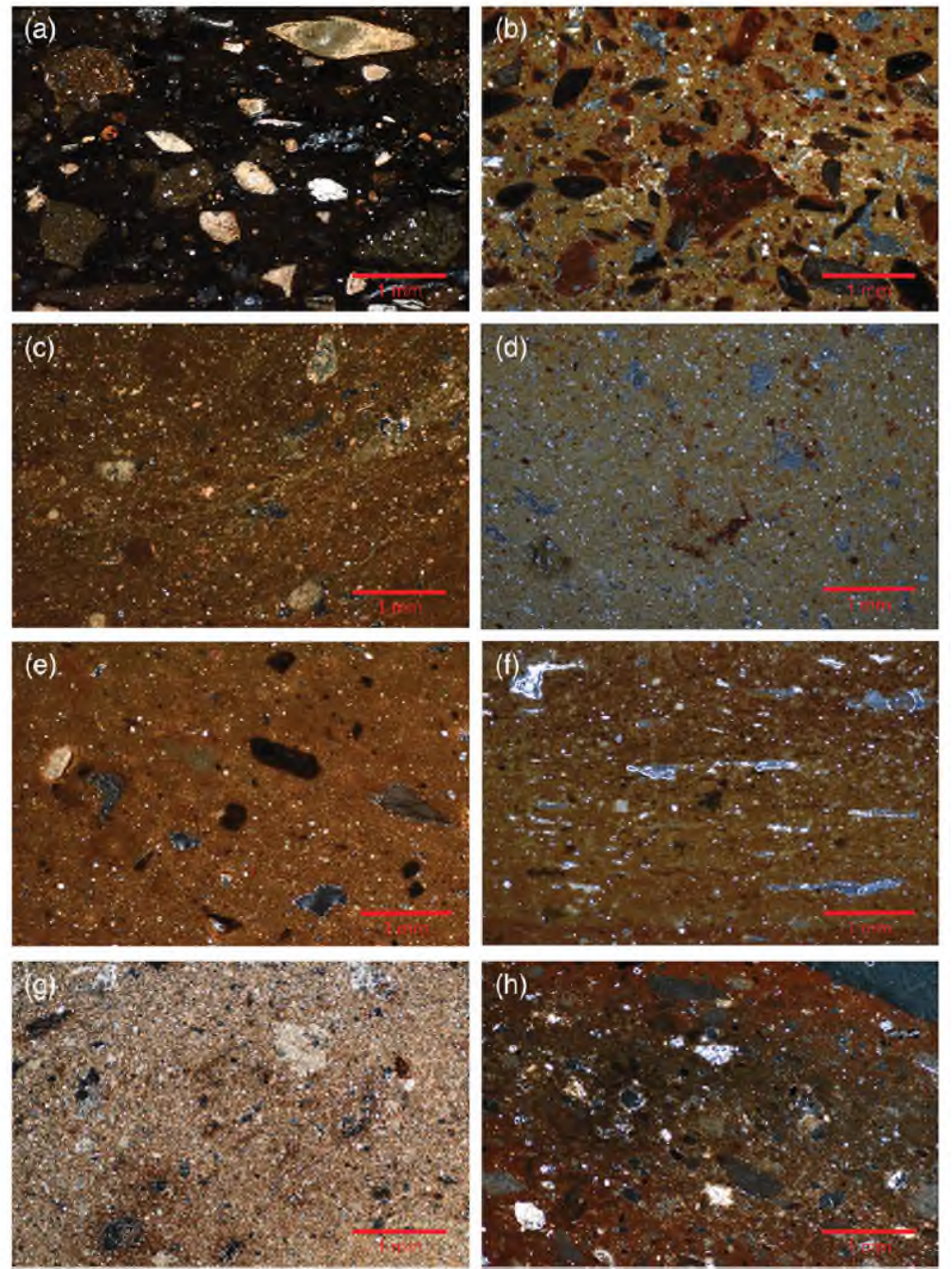

Figure 4 Thin-section photomicrographs of selected ceramics from each petrographic group: (a) Mudstone-limestone;(b) Mudstone - clay pellet; (c) Fine-grained A; (d) Fine-grained B; (e) Individual A; (f) Individual B; ( $g$ ) Individual C; (h) Individual D. 


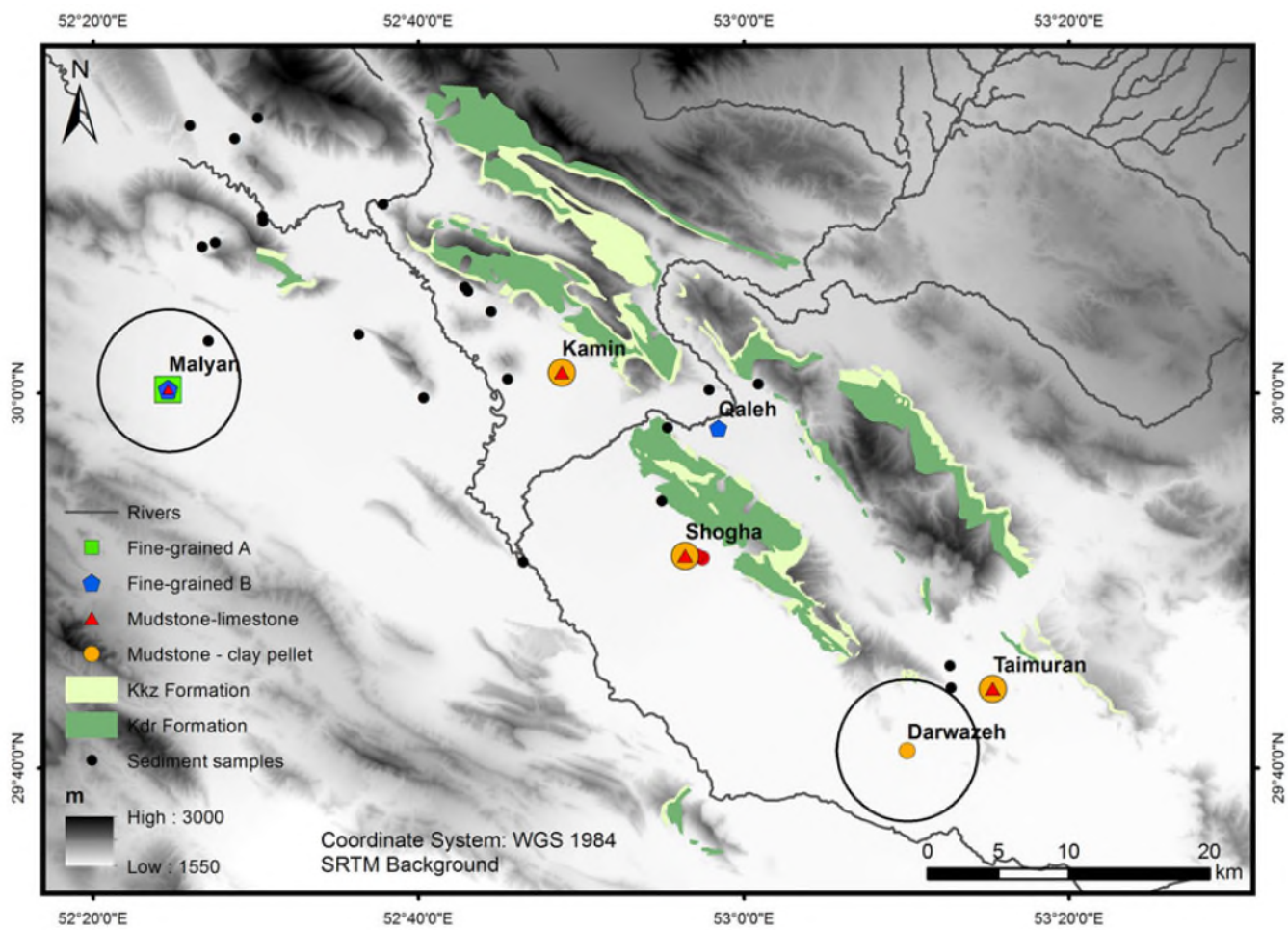

Figure 5 The location of the analysed clays and the two known production centres with a radius of $7 \mathrm{~km}$ around the sites. For the production of the Shogha and Taimuran ceramics, a possible source could be determined at the northern border of the circle around Darwazeh. 


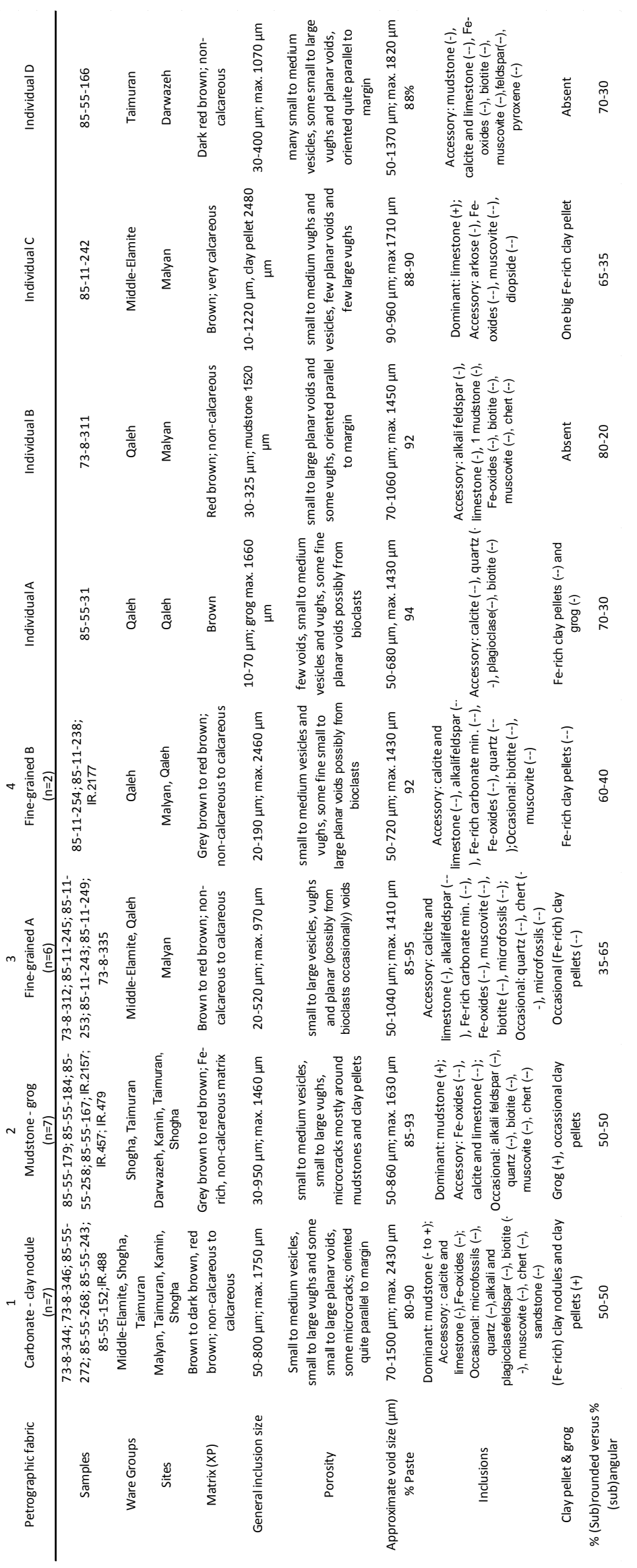

Table 1 The characteristics of the different petrographic groups and individuals 